\title{
NAC-loaded electrospun scaffolding system with dual compartments for the osteogenesis of rBMSCs in vitro [Erratum]
}

Zhu Y, Song F, Ju Y, et al. Int J Nanomedicine. 2019;14:

787-798.

On page 787, affiliation 1 was incorrectly listed, it should be as follows:

The State Key Laboratory Breeding Base of Basic Science of Stomatology (Hubei-MOST) \& Key Laboratory of Oral Biomedicine Ministry of Education (KLOBM), School \& Hospital of Stomatology, Wuhan University, Wuhan, Hubei, China.

\section{Publish your work in this journal}

The International Journal of Nanomedicine is an international, peerreviewed journal focusing on the application of nanotechnology in diagnostics, therapeutics, and drug delivery systems throughou the biomedical field. This journal is indexed on PubMed Central,

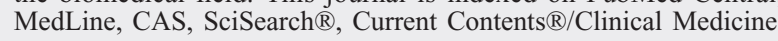

Journal Citation Reports/Science Edition, EMBase, Scopus and the Elsevier Bibliographic databases. The manuscript management system is completely online and includes a very quick and fair peer-review system, which is all easy to use. Visit http://www.dovepress.com/ testimonials.php to read real quotes from published authors.

Submit your manuscript here: http://www.dovepress.com/international-journal-of-nanomedicine-journal 